\title{
CAPITAL REGULATION AND ISLAMIC BANKING PERFORMANCE: PANEL EVIDENCE
}

\author{
Mansor H. Ibrahim ${ }^{1}$ \\ ${ }^{1}$ International Centre for Education in Islamic Finance, Kuala Lumpur, Malaysia. \\ Email: mansorhi@inceif.org
}

\begin{abstract}
This paper empirically assesses the relation between bank performance and capital regulation for Islamic banks from 13 countries and evaluates whether the relation varies with bank size, capital, and liquidity. We find small Islamic banks to be less stable and less profitable; they also cut lending growth as capital regulation becomes more stringent. The stability and lending growth of big Islamic banks are, however, directly related to capital regulation. Further, capital regulation adversely affects the profitability of Islamic banks with low liquidity and high capital holdings. While capital regulation is needed, it should not be adopted in a blanket manner for all Islamic banks.
\end{abstract}

Keywords: Capital regulation; Islamic banks; Z-score; Return on Assets; Lending growth. JEL Classification: C23; G21; G28.

Article history:

Received : January 17, 2019

Revised : : March 10, 2019

Accepted : : April 1, 2019

Available online : April 30, 2019

https://doi.org/10.21098/bemp.v22i1.1029 


\section{INTRODUCTION}

The rapid growth of Islamic banking in both size and complexity poses a key challenge in ensuring financial soundness in countries with both conventional and Islamic banks (IMF, 2017). While there are gaps and differences in Islamic banking regulatory frameworks across countries, Islamic banking is normally subject to the same banking regulations or regulatory environments as faced by conventional banks in their respective countries, particularly with respect to capital regulation and capital stringency requirements. Unfortunately, to date, there is a dearth of guidance in the literature on the effects of the stringency of capital requirements on Islamic bank performance. Moreover, existing findings for conventional banks may not be generalized to Islamic banks, due to their different business model. This begs the following questions: Is capital regulation of conventional banks applicable to Islamic banks? Is capital regulation effective in ensuring Islamic banking stability? Would capital regulation erode Islamic banking profitability or lending activity? And most importantly, does capital regulation fit Islamic banks with different bank-specific characteristics?

In light of these questions, the present paper assesses the relation between capital stringency regulation and Islamic banking performance. While we focus exclusively on capital stringency regulation, which aligns most closely to Basel capital standards, we contribute to the literature on the subject on various fronts. First, this paper provides a more comprehensive look at the issue for Islamic banks. While existing Islamic banking literature on the subject focuses mainly on only one aspect of performance, bank risk, we evaluate the implications of capital regulation on bank risk or stability, bank profitability, and lending behavior. Second, we address the question as to whether capital regulation fits Islamic banks with varying bank-specific characteristics. More specifically, we consider bank size, capital, and liquidity as potential factors that condition the relation between capital regulation and bank performance. And finally, we employ a panel sample of established Islamic banks across 13 dual-banking countries over a longer time-span than most existing Islamic banking studies, which allows us to leverage variations in capital regulation not only across countries but also across time. Principally, we contribute not only to the expanding literature on capital regulation and bank performance by focusing on the nascent but fast-growing Islamic banking sector, but also to enriching understanding and analysis of the Islamic banking sector.

Our results suggest that capital regulation does not affect all Islamic banks equally. Small Islamic banks seem to be more adversely affected; that is, they become less stable and less profitable and cut lending growth as capital regulation becomes more stringent. By contrast, the stability and lending growth of large Islamic banks are positively associated with capital regulation. We also find evidence indicating that the profitability of Islamic banks with low liquidity is adversely affected by capital regulation. Interestingly, capital regulation negatively affects the profitability of highly capitalized Islamic banks, while it has no implications for their stability and lending growth. These results hint at the importance of capital regulation for Islamic banks given that they have increased in size and complexity over the years. Still, capital regulation should not be adopted as a blanket rule 
applicable to all Islamic banks, especially in those countries where Islamic banks are small or in their infancy.

This paper unfolds as follows. Section II reviews the related literature. Section III details the variables and empirical models. Section IV presents estimation results and, finally, Section $\mathrm{V}$ sets forth conclusions.

\section{RELATED LITERATURE}

Capital regulation, which normally equates to capital requirements, and its relation to bank performance has been a subject of intense discussion, especially since the Global Financial Crisis. While capital regulation is intended to curb excessive risktaking and ensure bank stability, there have been concerns over its undesirable effects. Indeed, the literature highlights both positive and negative effects of capital regulation, see Triki et al. (2017), Deli and Hasan (2017), Bermpei et al. (2018) and references therein. On the positive side, by encouraging capital holdings in excess of minimum capital requirements, capital regulation reduces the moral hazard problem, enhances loss absorption capacity, and improves monitoring and control of risk by shareholders. As a result, banks become more stable and profitable and have greater ability to enhance credit growth. On the negative side, capital regulation may lead to reduced lending as a result of downward adjustments of risk-weighted assets to meet capital requirements. Moreover, it may weaken monitoring by lenders. Together with the fact that holding more capital than necessary is costly, banks may undertake more risk.

Existing empirical studies remain inconclusive as to the nature of the relation between capital regulation and bank performance. For instance, Agoraki et al. (2011) and Tan and Floros (2013) provide supporting evidence for a risk-mitigating effect of capital regulation. Likewise, Boudrigua et al. (2009) document a reduction in non-performing loans under more stringent capital requirements. Such requirements also lead banks to perform better and to be more efficient (Naceur and Kandil, 2009). By contrast, Osei-Assibey and Asenso (2015) provide support for an increase in non-performing loans under stringent capital regulation. In addition, De Nicolo (2015) finds a relatively large adverse effect of capital ratios on bank loans.

Some studies explore the possibility that documented variations in the relation between capital regulation and bank performance are shaped by such factors as bank-specific characteristics (Agoraki et al., 2011, Deli and Hasan, 2017, and Triki et al., 2017) and institutional quality (Fratzscher et al., 2016; Bermpei et al., 2018). Agoraki et al. (2011) evaluate whether bank market power shapes the effects of regulation on bank risk using a sample of 546 banks in 13 Central and Eastern European countries. The results suggest that the risk reduction effect of capital regulation is weakened or even reversed by market power. Deli and Hasan (2017) examine whether bank capital and liquidity affect the relation between capital regulation and loan growth using a worldwide sample from 125 countries. These authors document evidence indicating a negative effect of capital stringency on loan growth only for very low capitalized banks. However, over the longer term, there appear to be no permanent loan growth effects from more stringent 
capital regulation. Interestingly, they also document variations in the effects of different aspects of capital regulation. Focusing on 42 African countries, Triki et al. (2017) show that the efficiency gains from more stringent capital requirements materialize only for large banks and low risk banks. Using aggregate data from 50 advanced and emerging market economies, Fratzscher et al. (2016) document the substitute role of institutional quality for capital regulation in that the decline in credit growth and bank stability during the Global Financial Crisis is countered by greater supervisory independence; this counteracting effect is strongest in countries with poor institutions. Finally, evaluating the banking sectors of 69 emerging and developing economies, Bermpei et al. (2018) identify various aspects of institutions that condition the effects of bank regulation on stability. These include control of corruption, political stability, creditor rights, and rule of law.

Within the nascent and fast-growing Islamic banking sector, there is a clear concern over the impacts of capital regulation. This stems from the fact that capital regulations as per Basel requirements are designed for conventional banks but, once adopted by a country, they apply to Islamic banks as well (Zins and Weill, 2017). Unfortunately, the findings from existing studies may not be generalized to Islamic banks, given that Islamic banks differ from conventional banks in their adherence to Shariah or Islamic law.

While some studies consider bank capital either as a focal variable or a control variable in explaining Islamic bank performance, studies that focus directly on the effects of capital regulation on Islamic banks are rather scarce. Among the few recent studies in the literature, Alam (2014), Zins and Weill (2017), and Ibrahim and Rizvi (2017) are notable. Employing a panel sample of 70 Islamic banks and 165 conventional banks from 11 dual-banking countries, Alam (2014) focuses on the role of various banking regulations, including capital regulation, in shaping bank risk as measured by the ratio of loan loss reserves to total assets. These authors document evidence for the ability of capital requirements and private monitoring to mitigate risk-taking of both types of banks. Meanwhile, activity restrictions induce conventional banks to take more risk and Islamic banks to be more conservative. Zins and Weill (2017) generate evidence that Basel II is disadvantageous to Islamic banks because it widens the gap in risk between Islamic banks and conventional banks. Ibrahim and Rizvi (2017) focus principally on size-stability relations and, as an additional analysis, examine whether banking regulations impact Islamic banks of varying sizes differently. These authors document evidence suggesting more favorable effects on bank stability of regulation in the form of capital stringency and activity restrictions as bank size increases. The converse, however, holds for private monitoring and supervisory power.

The present study adds to this line of research. We follow the recent trend in the literature by focusing on bank-specific factors that likely condition the relation between capital regulation and Islamic bank performance, in addition to evaluating various dimensions of bank performance. 


\section{VARIABLES AND MODELS}

This section first explains the variables, then presents the empirical models used to address the research objectives, i.e., (i) to examine the impacts of capital regulation on Islamic banking stability, profitability, and lending growth, and (ii) to assess whether these impacts vary with bank size, capital, and liquidity.

\section{A. Variables}

The variables representing bank performance, which form the set of dependent variables, are bank stability, bank profitability, and bank lending growth. We use $Z$-score, computed as the sum of return on assets and equity-to-asset ratio divided by the standard deviation of asset return over a three-year rolling window, to represent bank stability. The $Z$-score is widely used in the literature. It captures the distance from insolvency, i.e., the number of standard deviations that asset return must fall to deplete capital. Following Cubillas and Gonzalez (2014), Anginer et al. (2014) and others, we express Z-score in the natural logarithmic form (LnZ). As for bank profitability, we use return on average assets (ROA), which measures the ability of a bank to generate return from its assets, and is viewed as a common and direct measure of bank profitability (Athanasoglou et al., 2008; Garcia-Herrero et al., 2009; Tan, 2016). Finally, bank lending growth is represented by the annual growth rate of gross loans $(\triangle \mathrm{LOAN})$. These three bank performance measures are common subjects of inquiry as to whether they are impacted by capital requirements (Agoraki et al., 2011; Naceur and Omran, 2011; Delis et al., 2012; Deli and Hasan, 2017; Triki et al., 2017; Bermpei et al., 2018).

The key explanatory variable is the capital regulation index $(C R)$ compiled by Barth et al. $(2006,2013)$. This index is based on various questions related to capital requirements from World Bank surveys, including whether the capital asset ratio is in line with Basel guidelines; whether it varies with market risk and unrealized loan losses; whether losses in securities portfolios and in foreign exchange are deducted from book value before minimum capital adequacy is determined; whether sources of funds used as capital are verified by regulatory/supervisory authorities; whether initial or subsequent injections of capital can be made using assets other than cash and government securities; and whether initial disbursement of capital can be made with borrowed funds. The surveys were published in 1998, 2002, 2006 and 2011 (Fratzscher et al., 2016). We follow Bermpei et al. (2018) in assigning values from the surveys to create the yearly capital regulation index. That is, the index from the 1998 survey is assigned to the 2000-2001 period, the 2002 survey index is assigned to the 2002-2005 period, the 2006 survey index is assigned to the 2006-2010 period, and the 2011 survey index is assigned to the 2011-2014 period. The index varies from 0 to 10, with higher values indicating greater capital stringency.

We also include as explanatory variables several bank-specific and macroeconomic variables normally considered in studies evaluating bank performance. There is heated discussion, especially since the Global Financial Crisis, on the "too big to fail" thesis vis-à-vis "economies of scale" advantages of large banks (Beccalli et al., 2015; Moutsianas and Kosmidou, 2016). Hence, we include bank size in the analysis. Following Cihak and Hesse (2010), Doumpos et al. (2015) 
and Triki at el. (2017), we measure bank size using the natural log of total assets (LnTA). In addition, it is widely viewed that bank capital and liquidity can absorb shocks, making banks more stable as a result, although both capital and liquidity tend to be more costly and yield lower returns. We use the equity-to-asset ratio (EQA) and liquid assets-to-total assets ratio (LIQA) to measure, respectively, bank capital and liquidity. These three bank-specific variables are almost always considered, especially in explaining bank loan supply or bank lending channels of monetary transmission mechanisms. In our case, we examine whether the impact of capital regulation on bank performance varies with these bank-specific characteristics, in line with the bank lending channel literature. Apart from these key bank-specific variables, we also include cost inefficiency as measured by the cost-to-income ratio (CIR); see, for instance, Delis et al. (2012) and Zins and Weill (2017). Finally, following Bermpei et al. (2018) and others, we include real GDP growth $(\Delta \mathrm{Y})$ and inflation (INF) to capture macroeconomic cycles and uncertainty, which would likely affect bank performance.

Data on bank-specific variables are sourced from Fitch Connect. The macroeconomic variables and capital regulation are from the World Development Indicators database and Barth et al. (2006, 2013).

\section{B. Empirical Models}

To assess the relation between capital regulation and Islamic bank performance, we begin with the following basic model:

$$
P F_{i t}=\beta_{0} P F_{i t-1}+\beta_{1} C R_{t}+\theta B S_{i t-1}+\varphi M A C_{t}+\mu_{i}+v_{i t}
$$

$P F$ is a measure of Islamic bank performance, namely, bank stability ( $L n Z)$, bank profitability $(R O A)$, or bank lending growth $(\triangle L O A N)$. We include the lagged performance measure to allow for its persistence. $C R$ is capital regulation. $B S$ is a vector of bank-specific variables. The common bank-specific variables across the three performance measures are bank size (LnTA), capital (EQA), liquidity $(L I Q A)$, and cost inefficiency (CIR). In addition, we include profitability and loan growth in the bank stability equation if they are significant. Similar treatment is applied to the profitability and lending growth equations. Note that these bank-specific variables are lagged by 1 to address the endogeneity concern. $M A C$ is a vector of macroeconomic variables, which includes real GDP growth $(\Delta Y)$ and inflation rate $(I N F) . \mu_{i}$ is individual fixed effects, and $v_{i t}$ is the standard disturbance term.

The key coefficient in (1) is $\beta_{1}$, which measures the relation between bank performance and capital regulation. While capital regulation aims to ensure bank stability, there is concern that it may place undue constraints on banks or have undesirable effects on bank performance. Moreover, capital regulation may not fit all banks equally. Accordingly, to address whether the impacts of capital regulation vary with bank-specific characteristics, we extend the model to include an interaction term as follows:

$$
P F_{i t}=\beta_{0} P F_{i t-1}+\beta_{1} C R_{t}+\beta_{2}\left(b s_{i t-1} \times C R_{t}\right)+\theta B S_{i t-1}+\varphi M A C_{t}+\mu_{i}+v_{i t}
$$


where $b s$ is one of the bank-specific variables, i.e., bank size, capitalization, and liquidity. By including the interaction term as in (2), the marginal effects of capital regulation on bank performance depend on $b s$. That is:

$$
\frac{\partial P F_{i t}}{\partial C R_{t}}=\beta_{1}+\beta_{2} b s_{i t-1}
$$

Thus, for concreteness, we compute and graph these marginal effects across $b s$ values as suggested by Brambor et al. (2006).

There are small variations in model specification across the three bank performance equations, and hence their estimation strategies. In particular, we drop the lagged dependent variable in the lending growth equation, since it turns out to be insignificant, and estimate it using the random-effects panel estimator. As for the other two equations, given lagged dependent variables in the equations, we adopt the two-step system GMM estimator for the dynamic panel models as suggested by Arellano and Bover (1995) and Blundell and Bond (1998), and employ the Windmeijer (2005) correction for downward bias in standard errors. We perform the standard Arellano-Bond test for autocorrelation and the Hansen test for instrument validity to ensure consistency of our estimates. We indicate other variations in model specification in the results section below.

\section{ESTIMATION RESULTS}

Our analysis focuses exclusively on Islamic banking and its relation to capital regulation. We gather bank-level data on Islamic banks from the following 13 dual-banking countries: Bahrain, Bangladesh, Egypt, Indonesia, Jordan, Kuwait, Malaysia, Pakistan, Qatar, Saudi Arabia, Tunisia, Turkey, and the United Arab Emirates. The panel data are unbalanced, covering the period 2000 to 2014.

Table 1.

\section{Variable Means by Country}

This table reports the means of the variables by country. $Z$-score $=$ the $Z$-score computed as the ratio of return on assets plus equity to asset ratio to the standard deviation of the return on assets, ROA = returns on average assets, $\triangle L O A N=$ the loan growth rate, $T A=$ total assets (in USD billion) , $E Q A=$ equity-to-assets ratio, $L I Q A=$ liquid assets to total assets ratio, $C I R=$ cost to income ratio, $\Delta Y=$ the real GDP growth rate, $I N F=$ inflation, and $C R=$ capital regulation index.

\begin{tabular}{lcccccccccc}
\hline & Z-score & ROA & $\Delta L O A N$ & $C R$ & TA & EQA & LIQA & CIR & $\Delta Y$ & INF \\
\hline Bahrain & 88.21 & 1.90 & 15.17 & 5.39 & $3,271.07$ & 20.88 & 18.15 & 58.69 & 5.14 & 2.14 \\
Bangladesh & 33.06 & 1.13 & 24.73 & 4.57 & $1,297.93$ & 6.85 & 19.34 & 45.90 & 5.80 & 6.76 \\
Egypt & 54.14 & -0.30 & 0.69 & 3.07 & $2,657.71$ & 5.44 & 19.02 & 71.54 & 4.14 & 8.52 \\
Indonesia & 37.16 & 1.19 & 29.12 & 4.00 & $2,240.94$ & 11.72 & 20.11 & 65.44 & 5.45 & 7.18 \\
Jordan & 42.01 & 1.35 & 12.98 & 5.53 & $1,357.05$ & 19.11 & 30.68 & 57.28 & 5.24 & 3.98 \\
Kuwait & 48.29 & 1.55 & 9.42 & 5.11 & $11,215.69$ & 14.88 & 24.02 & 60.39 & 5.01 & 1.93 \\
Malaysia & 82.04 & 0.76 & 17.12 & 4.94 & $7,680.70$ & 8.15 & 26.31 & 50.94 & 5.06 & 2.46 \\
Pakistan & 48.79 & 1.72 & 28.46 & 7.23 & $1,531.11$ & 9.50 & 21.76 & 55.26 & 4.28 & 10.23 \\
Qatar & 70.08 & 3.47 & 18.94 & 4.60 & $6,550.75$ & 16.34 & 23.90 & 28.95 & 11.55 & 4.21 \\
Saudi Arabia & 38.44 & 2.65 & 16.65 & 5.10 & $18,970.56$ & 15.94 & 23.35 & 50.37 & 5.28 & 3.22 \\
Tunisia & 124.71 & 1.70 & 11.30 & 4.71 & 393.76 & 21.72 & 39.51 & 48.13 & 3.72 & 7.34 \\
Turkey & 43.21 & 1.54 & 22.89 & 4.00 & $5,194.89$ & 10.78 & 20.10 & 73.53 & 4.17 & 13.56 \\
UAE & 109.37 & 2.32 & 21.4 & 5.41 & $8,805.11$ & 18.10 & 19.95 & 43.76 & 4.54 & 4.70 \\
\hline
\end{tabular}


We include only Islamic banks that have data available from 2005 or earlier, such that they cover at least two regulatory surveys by the World Bank. Given that the latest survey is from 2011, we view it reasonable to end our sample at 2014. With these considerations, we arrive at the final panel sample of 45 Islamic banks.

Table 2.

\section{Descriptive Statistics and Correlation Coefficients}

This table reports the descriptive statistics of the variables, namely their means and standard deviations and their pairwise correlation coefficients. $Z$-score $=$ the $Z$-score computed as the ratio of return on assets plus equity to asset ratio to the standard deviation of the return on assets, $R O A=$ returns on average assets, $\triangle L O A N=$ the loan growth rate, $T A=$ total assets (in USD billion) , EQA = equity-to-assets ratio, $L I Q A=$ liquid assets to total assets ratio, $C I R=$ cost to income ratio, $\Delta Y=$ the real GDP growth rate, $I N F=$ inflation, and $C R=$ capital regulation index.

\begin{tabular}{|c|c|c|c|c|c|c|c|c|c|c|c|c|}
\hline & \multicolumn{2}{|c|}{ Descriptive Stat } & \multicolumn{3}{|c|}{ Correlation Coefficients } & \multirow[b]{2}{*}{$T A$} & \multirow[b]{2}{*}{$E Q A$} & \multirow[b]{2}{*}{$L I Q A$} & \multirow[b]{2}{*}{ CIR } & \multirow[b]{2}{*}{$\Delta Y$} & \multirow[b]{2}{*}{ INF } & \multirow[b]{2}{*}{$C R$} \\
\hline & Mean & S.D. & Z-score & ROA & $\triangle L O A N$ & & & & & & & \\
\hline Z-Score & 62.359 & 122.65 & 1.00 & & & & & & & & & \\
\hline$R O A$ & 1.571 & 2.788 & 0.01 & 1.00 & & & & & & & & \\
\hline$\triangle L O A N$ & 0.174 & 0.266 & -0.07 & 0.21 & 1.00 & & & & & & & \\
\hline$T A$ & $5,757.20$ & $9,759.98$ & 0.12 & 0.11 & -0.06 & 1.00 & & & & & & \\
\hline$E Q A$ & 13.705 & 9.316 & 0.03 & 0.42 & -0.01 & -0.03 & 1.00 & & & & & \\
\hline LIQA & 22.198 & 12.771 & 0.01 & 0.00 & -0.07 & -0.15 & 0.01 & 1.00 & & & & \\
\hline$C I R$ & 54.756 & 51.352 & -0.06 & -0.53 & -0.00 & -0.12 & -0.02 & 0.03 & 1.00 & & & \\
\hline$\Delta Y$ & 5.269 & $3 . .300$ & -0.01 & 0.31 & 0.15 & -0.07 & 0.12 & 0.13 & -0.10 & 1.00 & & \\
\hline INF & 5.364 & 6.097 & -0.09 & 0.02 & 0.08 & -0.15 & -0.19 & 0.01 & -0.01 & 0.04 & 1.00 & \\
\hline$C R$ & 4.844 & 1.884 & 0.19 & -0.12 & -0.13 & 0.16 & 0.04 & -0.13 & 0.01 & -0.26 & -0.26 & 1.00 \\
\hline
\end{tabular}

Table 1 shows the means of the variables by country while Table 2 presents descriptive statistics and their pairwise correlation coefficients. Several observations arise from the tables. First, despite the rapid growth of the Islamic banking sector in these countries, there are marked variations in the performance of Islamic banks across the 13 countries. We find Islamic banks in Tunisia to be most stable and those in Bangladesh to be least stable, as indicated by the Z-score. In terms of profitability, Islamic banks in Qatar are ranked first, followed by banks in Saudi Arabia and UAE. Egyptian Islamic banks, however, record negative average profit over the sample period. They also have the lowest credit growth. In all countries, except Egypt and Kuwait, average annual growth of Islamic financing is in the double digits. Second, we observe differences in capital regulation, bankspecific characteristics and macroeconomic environments. Thus, these factors may potentially explain Islamic bank performance in these countries. Our focus here is on the role of capital regulation. Finally, we may infer from the low correlation coefficients for all pairs of explanatory variables that the multicollinearity problem should not be a major concern.

The estimation results are presented in Tables 3 to 5 for, respectively, bank stability, profitability, and lending growth. To ease interpretation and inferences on our key themes, we present the marginal effects of bank regulation on bank performance together with the $90 \%$ confidence interval for the three cases in Figures 1 to 3. Below, we discuss each case. 


\section{A. Capital Regulation and Bank Stability}

Table 3 reports regression results for the bank stability equation, while Figure 1 shows the marginal effects of capital regulation on bank stability. We find that using the first lag of the dependent variable is not sufficient to render the error terms uncorrelated. Accordingly, we extend the lagged dependent variable up to lag 2. Both the Hansen test statistics and the Arellano-Bond autocorrelation test statistics confirm the validity of the instruments and absence of autocorrelation in all regressions. Note that, in explaining Islamic bank stability, we find profitability to be significant and lending growth to be insignificant. Accordingly, we also include lagged-1 ROA alongside other bank-specific variables.

\section{Table 3.}

\section{Estimation Results - Bank Stability}

This table reports the regression results for bank stability equation. The numbers in parentheses are $p$-values. $L n Z=$ the natural $\log$ of the $Z$-score, $R O A=$ returns on average assets, $\triangle L O A N=$ the loan growth rate, $L n T A=$ the natural log of total assets, $E Q A=$ equityto-assets ratio, $L I Q A=$ liquid assets to total assets ratio, $C I R=$ cost to income ratio, $\triangle Y=$ the real GDP growth rate, INF = inflation, and $C R=$ capital regulation index. Column (1) estimates the model with no interaction terms as stated in equation (1). Meanwhile, columns (2)-(4) adds the interaction term, i.e. equation (2), where capital regulation is interacted alternatively with bank size, bank capital and bank liquidity. ${ }^{*} p<0.1,{ }^{* *} p<0.05,{ }^{* * * *} p<0.01$.

\begin{tabular}{lcccc}
\hline & $\mathbf{( 1 )}$ & $\mathbf{( 2 )}$ & $\mathbf{( 3 )}$ & $\mathbf{( 4 )}$ \\
\hline$L n Z_{t-1}$ & $0.7435^{* * *}$ & $0.6879^{* * *}$ & $0.7449^{* * *}$ & $0.7440^{* * *}$ \\
& $(0.000)$ & $(0.000)$ & $(0.000)$ & $(0.000)$ \\
$L n Z_{t-2}$ & $-0.2018^{* * *}$ & $-0.1945^{* * *}$ & $-0.2092^{* * *}$ & $-0.2047^{* * *}$ \\
& $(0.001)$ & $(0.001)$ & $(0.001)$ & $(0.000)$ \\
$L n T A_{t-1}$ & $0.2419^{* *}$ & -0.1686 & $0.2409^{* *}$ & $0.2447^{* * *}$ \\
& $(0.012)$ & $(0.475)$ & $(0.013)$ & $(0.010)$ \\
$E Q A_{t-1}$ & -0.0197 & -0.0194 & -0.0179 & -0.0197 \\
& $(0.131)$ & $(0.132)$ & $(0.401)$ & $(0.136)$ \\
$L I Q A_{t-1}$ & -0.0044 & -0.0035 & -0.0048 & 0.0063 \\
& $(0.557)$ & $(0.630)$ & $(0.538)$ & $(0.708)$ \\
& $-0.0020^{*}$ & $-0.0024^{* *}$ & $-0.0021^{*}$ & $-0.0020^{*}$ \\
$R O A_{t-1}$ & $(0.090)$ & $(0.017)$ & $(0.074)$ & $(0.084)$ \\
& $-0.1230^{* * *}$ & $-0.1144^{* * *}$ & $-0.1208^{* * *}$ & $-0.1245^{* * *}$ \\
$\Delta Y_{t}$ & $(0.007)$ & $(0.007)$ & $(0.010)$ & $(0.008)$ \\
& $0.0647^{* *}$ & $0.0640^{* *}$ & $0.0652^{* *}$ & $0.0628^{* *}$ \\
$I N F_{t}$ & $(0.019)$ & $(0.014)$ & $(0.016)$ & $(0.019)$ \\
& 0.0022 & 0.0047 & 0.0032 & 0.0018 \\
& $(0.806)$ & $(0.679)$ & $(0.743)$ & $(0.836)$ \\
& -0.0394 & $-1.2681^{* *}$ & -0.0347 & -0.0015 \\
& $(0.361)$ & $(0.033)$ & $(0.610)$ & $(0.981)$ \\
\hline
\end{tabular}


Table 3.

\section{Estimation Results - Bank Stability (contd.)}

This table reports the regression results for bank stability equation. The numbers in parentheses are $p$-values. $L n Z=$ the natural log of the $Z$-score, $R O A=$ returns on average assets, $\triangle L O A N=$ the loan growth rate, $L n T A=$ the natural log of total assets, $E Q A=$ equityto-assets ratio, $L I Q A=$ liquid assets to total assets ratio, $C I R=$ cost to income ratio, $\triangle Y=$ the real GDP growth rate, INF $=$ inflation, and $C R=$ capital regulation index. Column (1) estimates the model with no interaction terms as stated in equation (1). Meanwhile, columns (2)-(4) adds the interaction term, i.e. equation (2), where capital regulation is interacted alternatively with bank size, bank capital and bank liquidity. ${ }^{*} p<0.1,{ }^{* *} p<0.05,{ }^{* * *} p<0.01$.

(1)

(2)

(3)

(4)

\begin{tabular}{lcccc}
\hline$C R_{t} \times \operatorname{LnTA}_{t-1}$ & $0.0838^{* *}$ & \\
& & & \\
$C R_{t} \times E Q A_{t-1}$ & & & \\
& & $-0.045)$ & \\
$C R_{t} \times$ IQ $_{t-1}$ & & $(0.920)$ & \\
& & & -0.0004 \\
Constant & & & $(0.485)$ \\
& -1.4549 & 4.6603 & -1.4305 & -1.6828 \\
\hline \# Observations & $(0.303)$ & $(0.187)$ & $(0.301)$ & $(0.239)$ \\
\# Banks & 413 & 413 & 413 & 413 \\
P(Hansen) & 45 & 45 & 45 & 45 \\
P(AR1) & 0.2307 & 0.3003 & 0.2133 & 0.2553 \\
P(AR2) & 0.0001 & 0.0001 & 0.0001 & 0.0001 \\
\hline & 0.3077 & 0.2719 & 0.3365 & 0.2963 \\
\hline
\end{tabular}

Figure 1. Marginal Effects of Capital Regulation on Bank Stability

This figure plots the marginal effects of capital regulation on bank stability across bank-specific characteristics as suggested by Brambor et al. (2006). In the figure, the $90 \%$ confidence interval is provided together with the frequency distribution (histogram) of bank-specific characteristics in the background.

(a) Bank Size

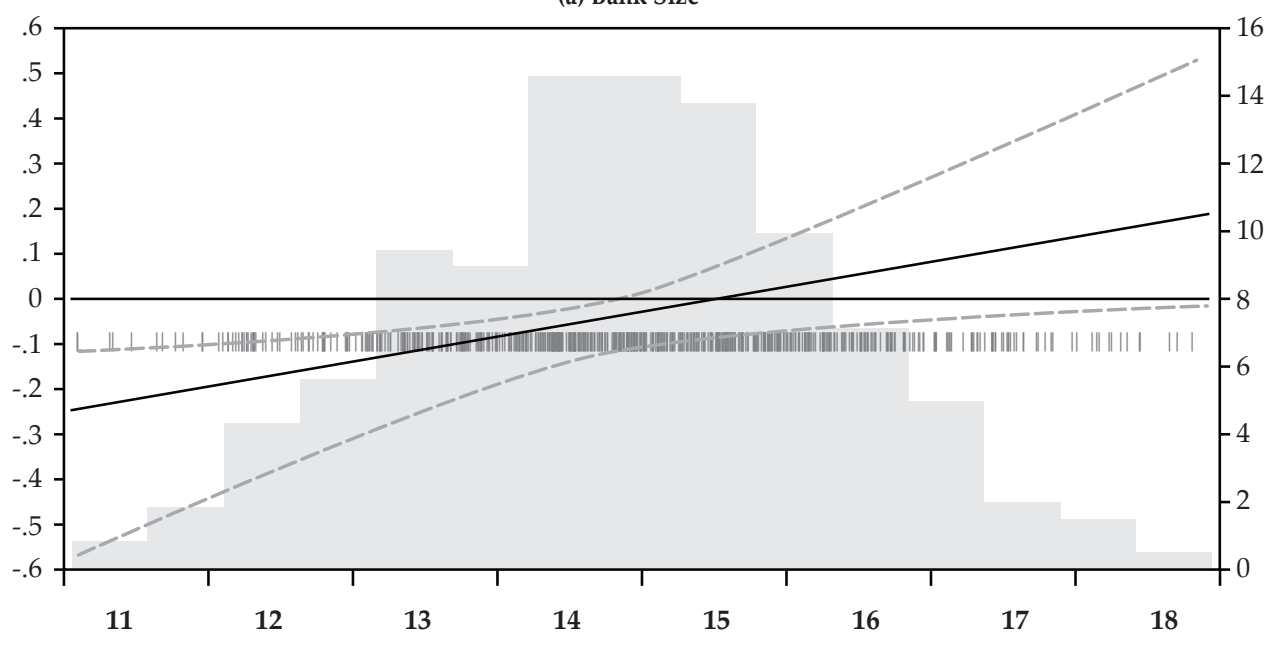




\section{Figure 1. Marginal Effects of Capital Regulation on Bank Stability (contd.)}

This figure plots the marginal effects of capital regulation on bank stability across bank-specific characteristics as suggested by Brambor et al. (2006). In the figure, the $90 \%$ confidence interval is provided together with the frequency distribution (histogram) of bank-specific characteristics in the background.

(b) Bank Capital

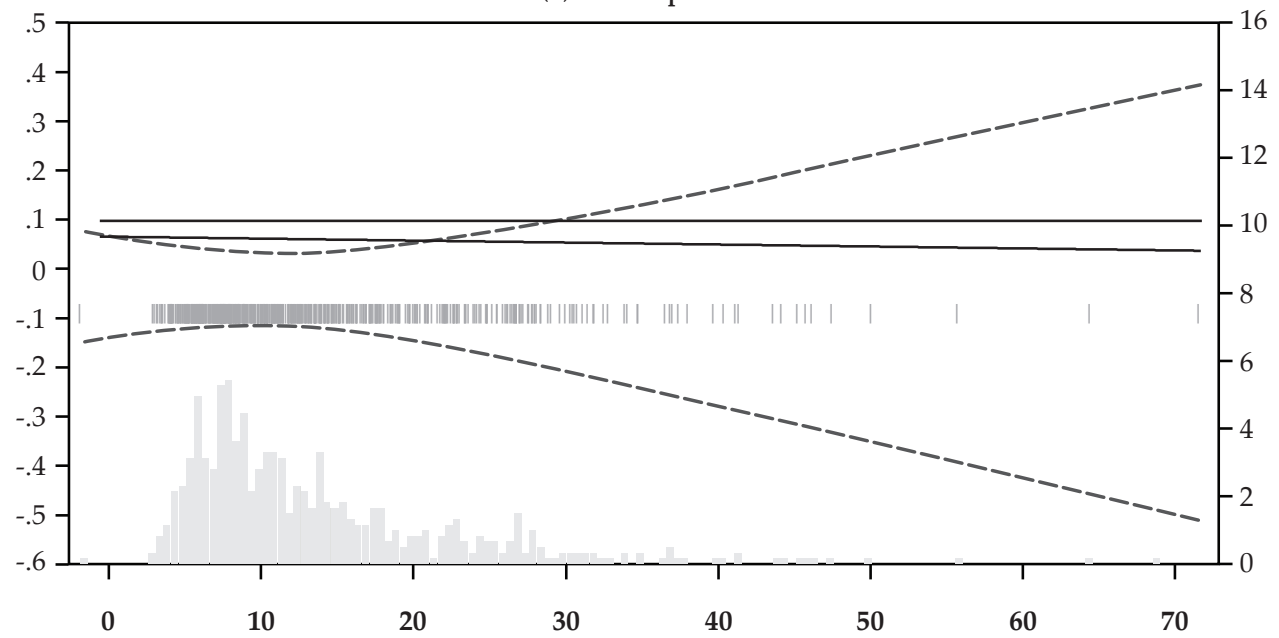

(c) Bank Liquidity

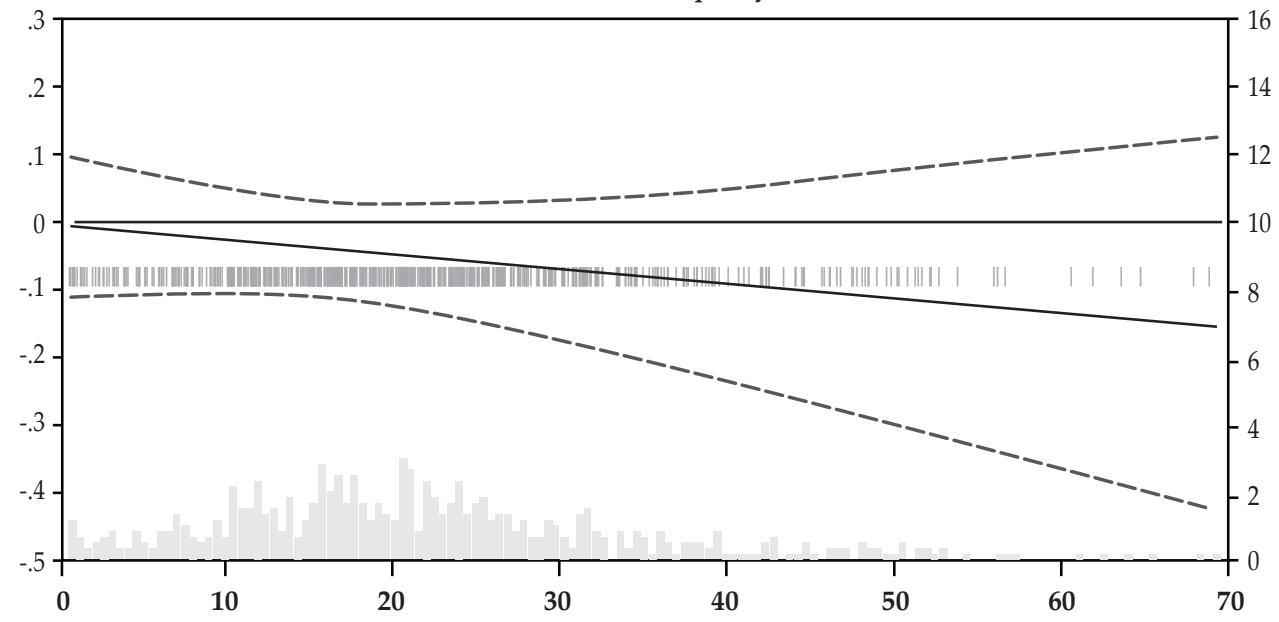

The results in column (1) of Table 3 indicate no significant effect of capital regulation on bank risk. However, when we include the capital regulation - bank size interaction, we find the coefficient of capital regulation and its interaction with bank size to be significant at the $5 \%$ level, with negative and positive signs, respectively. This means that capital regulation hurts small Islamic banks but helps large Islamic banks. Figure 1, panel (a), illustrates these marginal effects exhaustively across bank sizes. The graph clearly suggests that, for small Islamic banks, increasing capital regulation stringency makes them less stable. This negative effect of capital regulation, however, declines as banks become larger 
and, indeed, it turns positive for the largest bank in the sample, with assets over $\$ 82$ billion. This result is in line with Ibrahim and Rizvi (2017), which documents favorable effects of capital regulation for large banks. It is also in line with Triki et al. (2017), who find evidence suggesting efficiency gains from more stringent capital requirements for large banks.

When we interact capital regulation with bank capital or bank liquidity, neither capital regulation nor the interaction terms are significant. However, since the insignificance of the individual variables forming the interaction and of the interaction terms does not indicate the insignificance of the marginal effects at all levels of conditioned variables (i.e., capital and liquidity), we graph the corresponding marginal effects in panel (b) and panel (c) of Figure 1. Both suggest that the levels of bank capital and bank liquidity do not affect capital regulation stability relation.

As for the control variables, larger banks tend to be more stable and, as hinted by the results from column 2 of Table 3, the stability effect of bank size is enhanced by capital regulation stringency. In other words, as Islamic banks become large, greater capital regulation is needed to ensure their stability. Results also indicate that more profitable banks are less stable. Bokpin (2016) argues that if banks have overriding concerns over maintaining profitability, they take more risk. In line with this argument, in the process of ensuring profitability, Islamic banks take more risk. This would increase the variance of ROA and consequently lower Z-score or stability. Our results also indicate that inefficient Islamic banks are less stable, which should be expected. Finally, Islamic bank stability is positively associated with economic growth.

\section{B. Capital Regulation and Bank Profitability}

Table 4 reports results for the bank profitability equation. Accompanying these results is Figure 2, which plots the marginal effects of bank regulation on profitability across bank size, capital and liquidity. In this equation, bank stability and lending growth enter insignificantly in all regressions, hence their exclusion. The Hansen test statistics and Arellano-Bond autocorrelation test statistics reported at the bottom of Table 4 verify the consistency of the system GMM estimates. 
Table 4.

\section{Estimation Results - Bank Profitability}

This table reports the regression results for bank profitability equation. The numbers in parentheses are $p$-values. $L n Z=$ the natural $\log$ of the $Z$-score, $R O A=$ returns on average assets, $\triangle L O A N=$ the loan growth rate, $\operatorname{LnTA}=$ the natural $\log$ of total assets, $E Q A=$ equity-to-assets ratio, $L I Q A=$ liquid assets to total assets ratio, $C I R=$ cost to income ratio, $\Delta Y=$ the real GDP growth rate, INF = inflation, and $C R=$ capital regulation index. Column (1) estimates the model with no interaction terms as stated in equation (1). Meanwhile, columns (2)-(4) adds the interaction term, i.e. equation (2), where capital regulation is interacted alternatively with bank size, bank capital and bank liquidity. ${ }^{*} p<0.1,{ }^{* *} p<0.05,{ }^{* * *} p<0.01$.

\begin{tabular}{|c|c|c|c|c|}
\hline & (1) & (2) & (3) & (4) \\
\hline \multirow[t]{2}{*}{$R O A_{t-1}$} & $0.4416^{* * *}$ & $0.4425^{* * *}$ & $0.4435^{* * *}$ & $0.4370^{* * *}$ \\
\hline & $(0.000)$ & $(0.000)$ & $(0.000)$ & $(0.000)$ \\
\hline \multirow[t]{2}{*}{$\operatorname{LnTA} A_{t-1}$} & $-1.7519^{* * *}$ & $-1.9715^{* * *}$ & $-1.6762^{* * *}$ & $-1.7727^{* * *}$ \\
\hline & $(0.005)$ & $(0.004)$ & $(0.006)$ & $(0.004)$ \\
\hline \multirow{2}{*}{$E Q A_{t-1}$} & $-0.1697^{* * *}$ & $-0.1685^{* * *}$ & -0.0548 & $-0.1682^{* * *}$ \\
\hline & $(0.007)$ & $(0.008)$ & $(0.350)$ & $(0.007)$ \\
\hline \multirow[t]{2}{*}{$L I Q A_{t-1}$} & 0.0036 & 0.0040 & 0.0028 & -0.0128 \\
\hline & $(0.842)$ & $(0.827)$ & $(0.868)$ & $(0.583)$ \\
\hline \multirow[t]{2}{*}{$C I R_{t-1}$} & 0.0020 & 0.0023 & 0.0024 & 0.0019 \\
\hline & $(0.762)$ & $(0.727)$ & $(0.710)$ & $(0.764)$ \\
\hline \multirow[t]{2}{*}{$\Delta Y_{t}$} & $0.1739^{* *}$ & $0.1760^{* *}$ & $0.1741^{* *}$ & $0.1730^{* *}$ \\
\hline & $(0.026)$ & $(0.019)$ & $(0.018)$ & $(0.025)$ \\
\hline \multirow[t]{2}{*}{$I N F_{t}$} & 0.0266 & 0.0246 & 0.0266 & 0.0271 \\
\hline & $(0.243)$ & $(0.244)$ & $(0.241)$ & $(0.223)$ \\
\hline \multirow[t]{2}{*}{$C R_{t}$} & $-0.1156^{* *}$ & -1.0065 & 0.2239 & -0.1848 \\
\hline & $(0.048)$ & (0.194) & $(0.121)$ & $(0.153)$ \\
\hline \multirow[t]{2}{*}{$C R_{t} \times \operatorname{LnTA} A_{t-1}$} & & 0.0603 & & \\
\hline & & $(0.257)$ & & \\
\hline \multirow[t]{2}{*}{$C R_{t} \times E Q A_{t-1}$} & & & $-0.0251^{* *}$ & \\
\hline & & & $(0.015)$ & \\
\hline \multirow[t]{2}{*}{$C R_{t} \times L I Q A_{t-1}$} & & & & 0.0034 \\
\hline & & & & $(0.439)$ \\
\hline \multirow[t]{2}{*}{ Constant } & $28.1430^{* * *}$ & $31.3945^{* * *}$ & $25.4947^{* * *}$ & $28.7389^{* * *}$ \\
\hline & $(0.005)$ & $(0.003)$ & $(0.006)$ & $(0.003)$ \\
\hline \# Observations & 539 & 539 & 539 & 539 \\
\hline \# Banks & 45 & 45 & 45 & 45 \\
\hline P(Hansen) & 0.3640 & 0.4247 & 0.4568 & 0.3778 \\
\hline $\mathrm{P}(\mathrm{AR} 1)$ & 0.0651 & 0.0627 & 0.0513 & 0.0618 \\
\hline $\mathrm{P}(\mathrm{AR} 2)$ & 0.9955 & 0.9980 & 0.9346 & 0.9646 \\
\hline
\end{tabular}




\section{Figure 2. Marginal Effects of Capital Regulation on Bank Profitability}

This figure plots the marginal effects of capital regulation on bank profitability across bank-specific characteristics as suggested by Brambor et al. (2006). In the figure, the $90 \%$ confidence interval is provided together with the frequency distribution (histogram) of bank-specific characteristics in the background.

(a) Bank Size

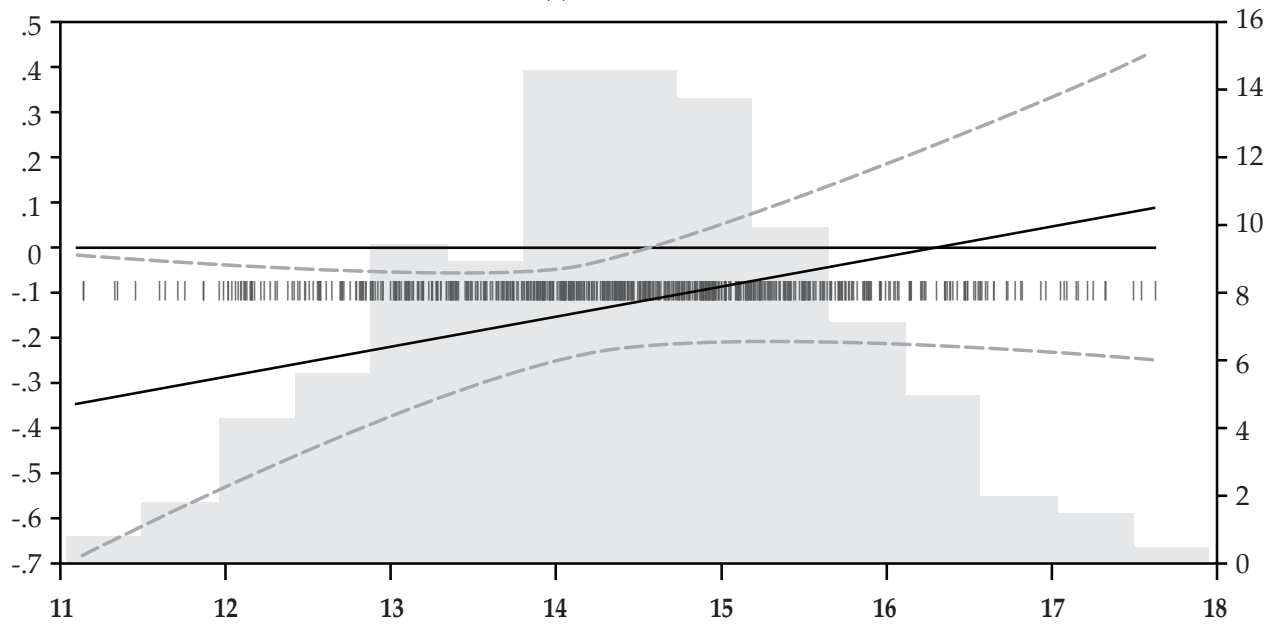

(b) Bank Capital

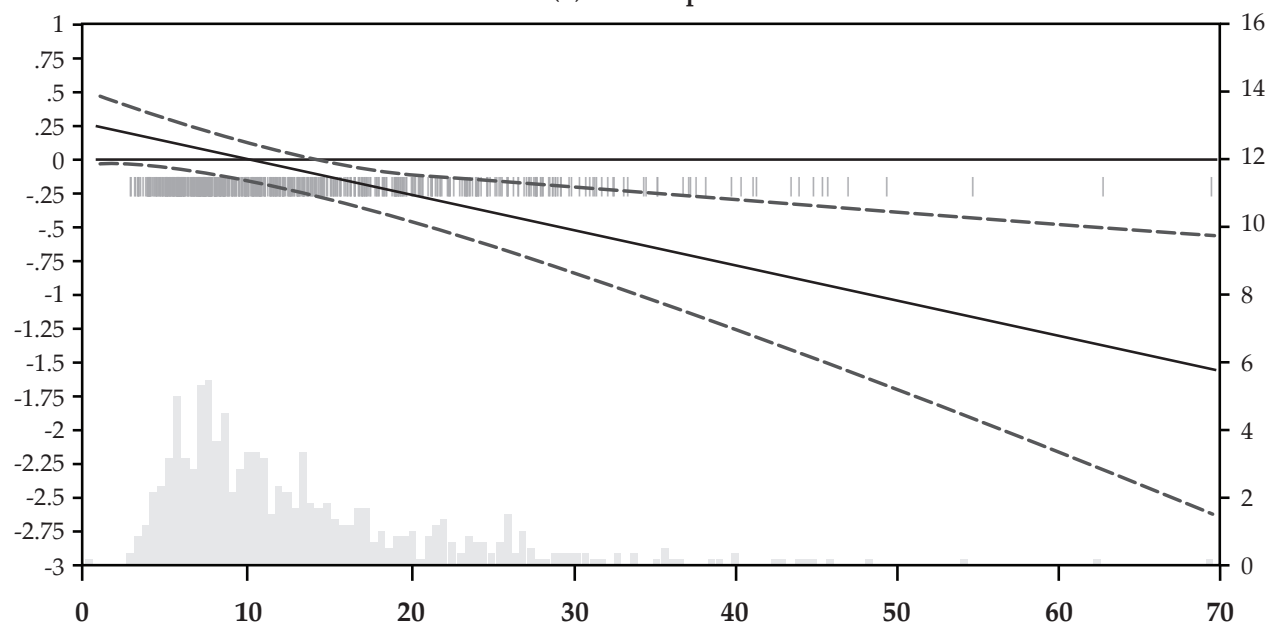


Figure 2. Marginal Effects of Capital Regulation on Bank Profitability (contd.)

This figure plots the marginal effects of capital regulation on bank profitability across bank-specific characteristics as suggested by Brambor et al. (2006). In the figure, the $90 \%$ confidence interval is provided together with the frequency distribution (histogram) of bank-specific characteristics in the background.

(c) Bank Liquidity

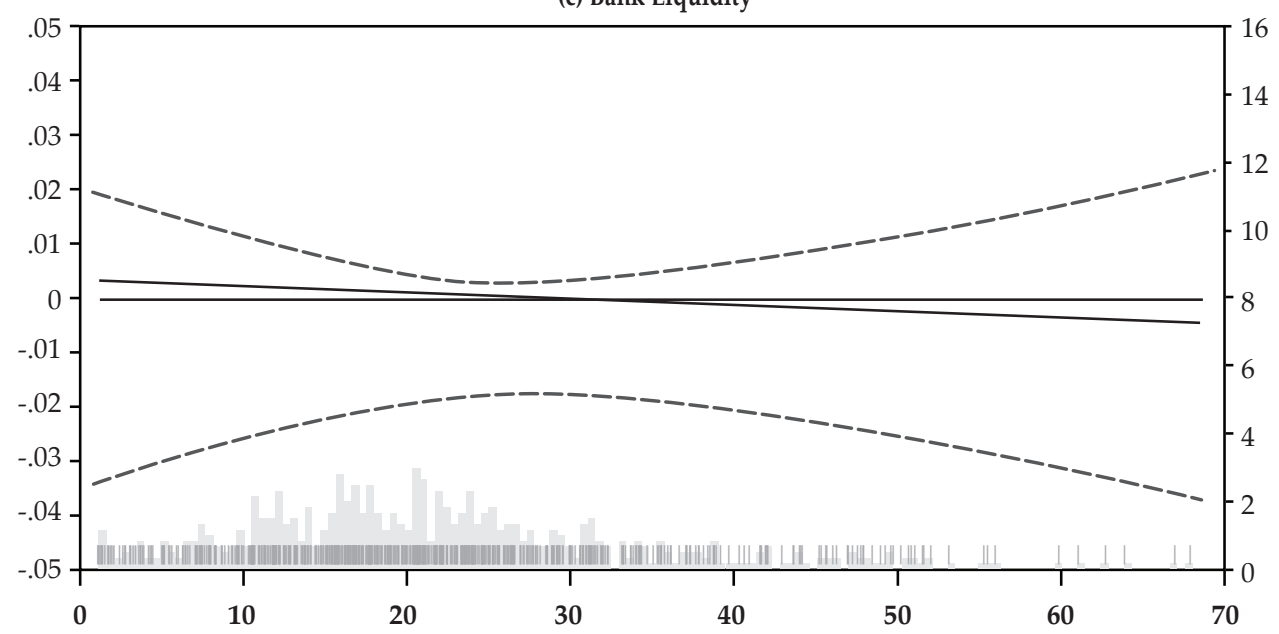

In column (1), the coefficient of capital regulation $(C R)$ is negative and significant at the $5 \%$ significance level. This suggests a reduction of profitability of 0.11 percentage point as the level of capital stringency increases by 1 point. When we interact capital regulation with the three bank-specific variables (i.e., size, capital, and liquidity), the CR coefficient turns insignificant. Moreover, among the interaction terms, only capital regulation - capital interaction is significant (column 3). As noted above, in models with an interaction term, assessing the significance of the variables forming the interaction term must be based on the marginal effects as given in equation (3), and not independently on the coefficients of CR and the interaction terms. The marginal effects, as plotted in Figure 2, demonstrate that basing interpretation on the two coefficients separately would be misleading. The plots all indicate the role of bank size, capital, and liquidity in influencing the relation between capital regulation and profitability. Again, we note that small Islamic banks tend to be adversely affected by capital regulation. Moreover, low-liquidity Islamic banks suffer a drop in profitability as capital regulation becomes more stringent. Thus, for these small and low-liquidity Islamic banks, capital regulation is costly. Also, we find no significant impact of capital regulation on profitability of large Islamic banks. These results may be explained in light of the findings of Zins and Weill (2017) and our finding in section 4.1. Since capital requirements are disadvantageous to Islamic banks, that is, as Islamic banks become more risky, their profitability suffers. Large Islamic banks, however, are likely to be in a better position to manage risk and diversify their sources of income.

Interestingly, we note that profitability of highly capitalized Islamic banks is adversely affected by capital regulation (Figure 2, panel (b)). Perhaps holding high 
levels of capital is suboptimal and capital stringency further imposes constraints on the banks; as a result, profitability drops. In other words, this result may reflect the costs of both capital and capital regulation.

As for the control variables, we find profitability to be negatively related to bank size and equity-to-asset ratio. The likely explanation for the lower profitability of large Islamic banks is their concentration on financing activity or limited avenues for income diversification. Meanwhile, capital is costly to Islamic banks as noted above and, accordingly, Islamic banks with high levels of capital are less profitable. Finally, bank profitability is directly associated with GDP growth.

\section{Capital Regulation and Bank Loans}

Table 5 presents the estimation results for the loan growth equation, while Figure 3 plots the marginal effects of capital regulation on loan growth across bank sizes and levels of bank capital and liquidity. In conformity with Ibrahim and Rizvi (2018), the loan growth of Islamic banks does not exhibit persistence. That is, the lagged dependent variable is not significantly different from 0 . Accordingly, we drop the lagged dependent variable from the equation. In addition, we find profitability to be significant, while risk is not significant. This leads us to include lagged-1 profitability together with other bank-specific variables as control variables in the equation. We estimate the equation using the random-effects panel estimator such that generalization from the results is reasonable.

\section{Table 5.}

\section{Estimation Results - Bank Loan Growth}

This table reports the regression results for loan growth equation. The numbers in parentheses are $p$-values. $L n Z=$ the natural $\log$ of the $Z$-score, $R O A=$ returns on average assets, $\triangle L O A N=$ the loan growth rate, $\operatorname{LnTA}=$ the natural $\log$ of total assets, $E Q A=$ equity-to-assets ratio, $L I Q A=$ liquid assets to total assets ratio, $C I R=$ cost to income ratio, $\Delta Y=$ the real GDP growth rate, $I N F=$ inflation, and $C R=$ capital regulation index. Column (1) estimates the model with no interaction terms as stated in equation (1). Meanwhile, columns (2)-(4) adds the interaction term, i.e. equation (2), where capital regulation is interacted alternatively with bank size, bank capital and bank liquidity. ${ }^{*} p<0.1,{ }^{* *} p<0.05,{ }^{* * *} p<0.01$.

\begin{tabular}{lcccc}
\hline & $\mathbf{( 1 )}$ & $\mathbf{( 2 )}$ & $\mathbf{( 3 )}$ & $\mathbf{( 4 )}$ \\
\hline nnTA $_{t-1}$ & $-0.0301^{* *}$ & $-0.0920^{* * *}$ & $-0.0296^{* *}$ & $-0.0303^{* *}$ \\
& $(0.017)$ & $(0.004)$ & $(0.015)$ & $(0.017)$ \\
$E Q A_{t-1}$ & -0.0003 & -0.0006 & 0.0034 & -0.0003 \\
& $(0.841)$ & $(0.656)$ & $(0.406)$ & $(0.857)$ \\
$\operatorname{LIQA}_{t-1}$ & $0.0043^{* * *}$ & $0.0041^{* * *}$ & $0.0041^{* * *}$ & 0.0047 \\
& $(0.001)$ & $(0.001)$ & $(0.002)$ & $(0.130)$ \\
CIR & 0.0004 & 0.0004 & 0.0004 & 0.0004 \\
& $(0.302)$ & $(0.297)$ & $(0.321)$ & $(0.300)$ \\
$R O A_{t-1}$ & $0.0193^{* * *}$ & $0.0200^{* * *}$ & $0.0191^{* * *}$ & $0.0193^{* * *}$ \\
& $(0.000)$ & $(0.000)$ & $(0.000)$ & $(0.000)$ \\
$\Delta Y t$ & $0.0072^{*}$ & $0.0079^{* *}$ & $0.0069^{*}$ & $0.0071^{*}$ \\
& $(0.078)$ & $(0.045)$ & $(0.098)$ & $(0.075)$ \\
\hline
\end{tabular}


Table 5.

\section{Estimation Results - Bank Loan Growth (contd.)}

This table reports the regression results for loan growth equation. The numbers in parentheses are $p$-values. $L n Z=$ the natural $\log$ of the $Z$-score, $R O A=$ returns on average assets, $\triangle L O A N=$ the loan growth rate, $\operatorname{LnTA}=$ the natural $\log$ of total assets, $E Q A=$ equity-to-assets ratio, $L I Q A=$ liquid assets to total assets ratio, $C I R=$ cost to income ratio, $\Delta Y=$ the real GDP growth rate, INF = inflation, and $C R=$ capital regulation index. Column (1) estimates the model with no interaction terms as stated in equation (1). Meanwhile, columns (2)-(4) adds the interaction term, i.e. equation (2), where capital regulation is interacted alternatively with bank size, bank capital and bank liquidity. ${ }^{*} p<0.1,{ }^{* *} p<0.05,{ }^{* * *} p<0.01$.

\begin{tabular}{|c|c|c|c|c|}
\hline & (1) & (2) & (3) & (4) \\
\hline \multirow[t]{2}{*}{$I N F_{t}$} & 0.0027 & 0.0030 & 0.0029 & 0.0027 \\
\hline & $(0.193)$ & $(0.173)$ & $(0.175)$ & $(0.197)$ \\
\hline \multirow[t]{2}{*}{$C R_{t}$} & 0.0012 & $-0.1906^{* *}$ & 0.0119 & 0.0029 \\
\hline & $(0.848)$ & $(0.017)$ & $(0.259)$ & $(0.823)$ \\
\hline \multirow[t]{2}{*}{$C R_{t} \times \operatorname{LnTA}_{t-1}$} & & $0.0130^{* *}$ & & \\
\hline & & $(0.015)$ & & \\
\hline \multirow[t]{2}{*}{$C R_{t} \times E Q A_{t-1}$} & & & -0.0008 & \\
\hline & & & $(0.277)$ & \\
\hline \multirow{2}{*}{$C R_{t} \times \operatorname{LIQ} A_{t-1}$} & & & & -0.0001 \\
\hline & & & & $(0.865)$ \\
\hline \multirow[t]{2}{*}{ Constant } & $0.4077^{* *}$ & $1.3109^{* * *}$ & $0.3587^{*}$ & $0.4020^{*}$ \\
\hline & $(0.042)$ & $(0.005)$ & $(0.062)$ & $(0.057)$ \\
\hline \# Observations & 539 & 539 & 539 & 539 \\
\hline \# Banks & 45 & 45 & 45 & 45 \\
\hline R-Squared & 0.1166 & 0.1296 & 0.1196 & 0.1166 \\
\hline
\end{tabular}

\section{Figure 3. Marginal Effects of Capital Regulations on Lending Growth}

This figure plots the marginal effects of capital regulation on loan growth across bank-specific characteristics as suggested by Brambor et al. (2006). In the figure, the $90 \%$ confidence interval is provided together with the frequency distribution (histogram) of bank-specific characteristics in the background.

(a) Bank Size

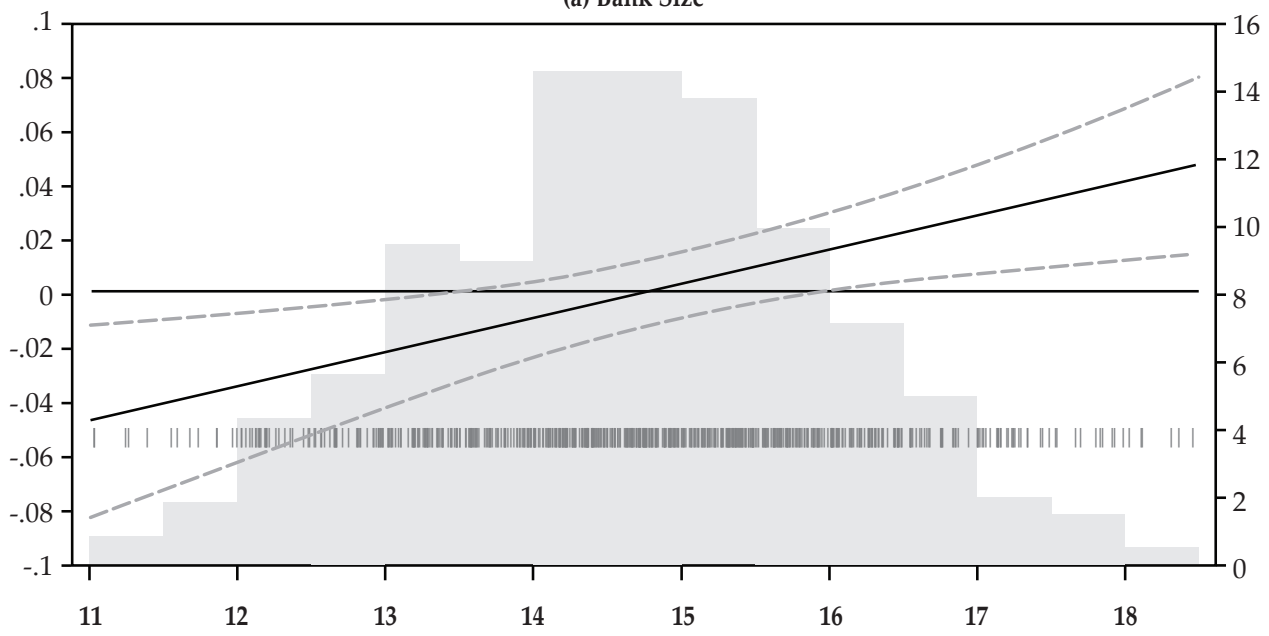


Figure 3. Marginal Effects of Capital Regulations on Lending Growth (contd.)

This figure plots the marginal effects of capital regulation on loan growth across bank-specific characteristics as suggested by Brambor et al. (2006). In the figure, the $90 \%$ confidence interval is provided together with the frequency distribution (histogram) of bank-specific characteristics in the background.

(b) Bank Capital

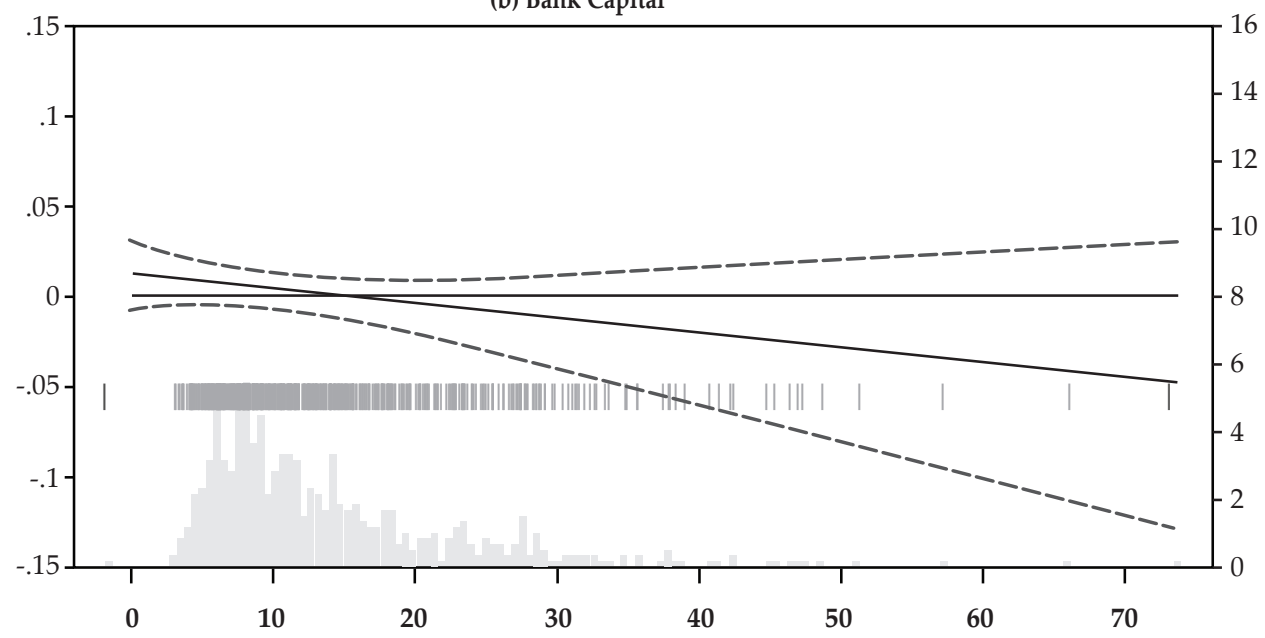

(c) Bank Liquidity

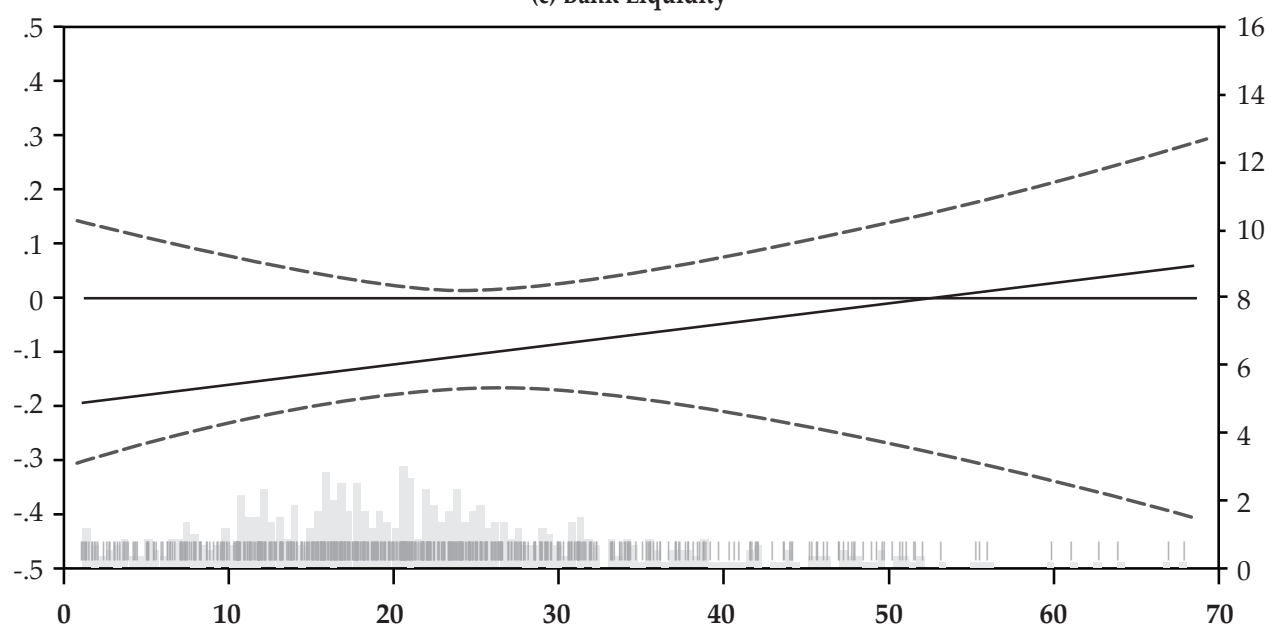

Again, bank size emerges as a significant factor shaping the relation between capital regulation and loan growth. Only in column (2), where we interact capital regulation with size, do we find both capital regulation and the interaction term to be significant. These results suggest that, for small Islamic banks, capital regulation stringency curtails loan growth. This negative effect of capital regulation on loan growth, however, is reversed when Islamic banks become larger. The marginal effects plotted in Figure 3, panel (a), reaffirm this interpretation. As for capital and liquidity, we do not find evidence suggesting that they condition the capital 
regulation - loan growth relation (see Figure 3). This finding is in line with the evidence provided in Deli and Hasan (2017) for a worldwide sample of banks. Although these authors note the significant role of bank capital in shaping the relation between capital requirements and credit growth, there is no permanent effect of capital regulation on loan growth.

As for the other control variables, we find a reduction in loan growth as bank size increases. Viewed together with the positive coefficient of the capital regulation - size interaction, i.e., column (2), the increase in loan growth by large banks materializes under stringent capital regulation requirements. This reaffirms our conclusion as to capital regulation and bank stability that, as Islamic banks become larger, more capital regulation is needed. We also find evidence that more liquid and more profitable banks tend to lend more. Finally, in line with many studies, we find lending growth of Islamic banks to move in tandem with business cycles (Ibrahim, 2016).

\section{CONCLUSION}

The Islamic banking sector has expanded rapidly over the years in many countries, especially in Malaysia and the Middle East. Being financial intermediaries, Islamic banks normally face the same regulatory environments as those initially designed for conventional banks, such as the Basel capital requirements and regulations. Given institutional differences between Islamic and conventional banks, the results obtained for conventional banks may not be applicable to Islamic banks. Thus, we assess the relation between capital regulation and Islamic bank risk, profitability, and loan growth and evaluate whether their relation varies with bank size, capital, and liquidity. Our results indicate heterogeneities in their relations, which are mainly conditioned by bank size.

More specifically, small banks are less stable, less profitable, and cut loan growth in the face of more stringent capital regulations. These negative effects, however, are subdued or even reversed when banks become larger. We also uncover evidence that the benefits of having large Islamic banks, in the form of improved stability and higher loan growth, manifest only when stringent capital regulation is in place. Apart from these findings, we also document evidence that the profitability of Islamic banks with low liquidity is adversely affected by capital regulation. Interestingly, the profitability of highly capitalized Islamic banks is also negatively affected by capital regulation. This may reflect the costly nature of both capital and capital regulation.

The policy implications of our results are clear. Capital regulation is important for Islamic banks, especially in countries where Islamic banks have grown in size and complexity. However, given the observed heterogeneities in the relation between capital regulation and bank performance, capital regulation should not be adopted blindly as a one-size-fits-all rule, especially in countries where Islamic banks are small or at the beginning stage of development. 


\section{REFERENCES}

Agoraki, M.E. K., Delis, M.D., and Pasiouras, F. (2011). Regulations, Competition and Bank Risk-Taking in Transition Countries. Journal of Financial Stability, 7, 38-48.

Alam, N. (2014). Regulations and Bank Risk Taking in Dual Banking Countries. Journal of Banking Regulation, 15, 105-116.

Anginer, D., Demirguc-Kunt, A., and Zhu, M. (2014). How Does Deposit Insurance Affect Bank Risk? Evidence from the Recent Crisis. Journal of Banking and Finance, 48, 312-321.

Arellano, M., and Bover, O. (1995). Another Look at the Instrumental Variable Estimation of Error-Components Models. Journal of Econometrics, 68, 29-51.

Athenasoglou, P.P., Brissimis, N.S., and Delis, M.D. (2008). Bank-Specific, Industry-Specific and Macroeconomic Determinants of Bank Stability. Journal of International Financial Markets, Institutions \& Money, 18, 121-136.

Barth, J.R., Caprio, G., and Levine, R. (2006). Rethinking Bank Regulation: Till Angels Govern. Cambridge: Cambridge University Press.

Barth, J. R. Jr., Caprio, G., and Levine, R. (2013). Bank Regulation and Supervision in 180 Countries from 1999 to 2011. Journal of Financial Economic Policy, 5, 111219.

Beccalli, E., Anolli, M., and Borello, G. (2015). Are European Banks Too Big? Evidence on Economies of Scale. Journal of Banking and Finance, 58, 232-246.

Bermpei, T., Kalyvas, A., and Nguyen, T.C. (2018). Does Institutional Quality Condition the Effect of Bank Regulations and Supervision on Bank Stability? Evidence from Emerging and Developing Economies. International Review of Financial Analysis, 59, 255-275.

Blundell, R., and Bond, R. (1998). Initial Conditions and Moment Restrictions in Dynamic Panel Data Models. Journal of Econometrics, 87, 115-143.

Boudrigua, A., Taktak, N.B., and Jellouli, S. (2009). Banking Supervision and NonPerforming Loans: A Cross-Country Analysis. Journal of Financial Economic Policy, 1, 286-318.

Brambor, T., Clark, W.R., and Golder, M. (2006). Understanding Interaction Models: Improving Empirical Analyses. Political Analysis, 14, 63-82.

Cihak, M., and Hesse, H. (2010). Islamic Banks and Financial Stability: An Empirical Analysis. Journal of Financial Services Research, 38, 95-113.

Cubillas, E., and Gonzalez, F., 2014. Financial Liberalization and Risk-Taking: International Evidence. Journal of Financial Stability, 11, 32-48.

De Nicolo, G. (2015). Revisiting the Impact of Bank Capital Requirements on Lending and Real Activity. IMF and CESifo.

Deli, Y.D., and Hasan, I. (2017). Real Effects of Bank Capital Regulations: Global Evidence. Journal of Banking and Finance, 82, 217-228.

Delis, M.D., Tran, K.C., and Tsionas, E.G. (2012). Quantifying and Explaining Parameter Heterogeneity in the Capital Regulation - Bank Risk Nexus. Journal of Financial Stability, 8, 57-68.

Doumpos, M., Gaganis, C., and Pasiouras, F. (2015). Central Bank Independence, Financial Supervision Structure and Bank Soundness: An Empirical Analysis Around the Crisis. Journal of Banking and Finance, 61, S69-S83. 
Fratzscher, M., Konig, P.J., and Lambert, C. (2016). Credit Provisions and Banking Stability After the Great Financial Crisis: The Role of Bank Regulation and the Quality of Governance. Journal of International Money and Finance, 66, 113-135.

Garcia-Herrero, A., Gavila, S., and Santabarbara, D., 2009. What Explains the Low Profitability of Chinese Banks? Journal of Banking and Finance, 33, 2080-2092.

Ibrahim, M.H. (2016). Business Cycle and Bank Lending Procyclicality in a Dual Banking System. Economic Modelling, 55, 127-134.

Ibrahim, M.H., and Rizvi, S.A.R. (2018). Bank Lending, Deposits and Risk-Taking in Times Of Crisis: A Panel Analysis of Islamic and Conventional Banks. Emerging Markets Review, 35, 31-47.

Ibrahim, M.H., and Rizvi, S.A.R. (2017). Do We Need Bigger Islamic Banks? An Assessment of Bank Stability. Journal of Multinational Finance Management, 40, 77-91.

International Monetary Fund. (2017). Multi-Country Report: Ensuring Financial Stability in Countries with Islamic Banking. IMF Country Report No. 17/145.

Moutsianas, K.A., and Kosmidou, K. (2016). Banking Earnings Volatility in the UK: Does Size Matter? A Comparison Between Commercial and Islamic Banks. Research in International Business and Finance, 38, 137-150.

Naceur, S. B., and Kandil, M. (2009). The Impact of Capital Requirements on Banks' Cost Of Intermediation and Performance: The Case of Egypt. Journal of Economics and Business, 61, 70-89.

Naceur, S.M., and Omran, M. (2011). The Effects of Bank Regulations, Competition, and Financial Reforms on Banks' Performance. Emerging Markets Review, 12, $1-20$.

Osei-Assibey, R., and Asenso, J.K. (2015). Regulatory Capital and Its Effect on Credit Growth, Non-Performing Loans and Bank Efficiency: Evidence from Ghana. Journal of Financial Economic Policy, 7, 401-420.

Tan, Y. (2016). The Impacts of Risk and Competition on Bank Profitability in China. Journal of International Financial Markets, Institutions \& Money, 40, 85-110.

Tan, Y., and Floros, C. (2013). Risk, Capital and Efficiency in Chinese Banking. Journal of International Financial Markets Institutions and Money, 26, 378-393.

Triki, T., Kouki, I., Dhaou, M.B., and Calice, P. (2017). Bank Regulation and Efficiency: What Works for Africa? Research in International Business and Finance, 39, 183-205.

Windmeijer, F. (2005). A Finite Sample Correction for the Variance of Linear Coefficient Two-Step GMM Estimators. Journal of Econometrics, 126, 25-51.

Zins, A., and Weill, L. (2017). Islamic Banking and Risk: The Impact of Basel II. Economic Modelling, 64, 626-637. 
This page is intentionally left blank 